\title{
Potential measures towards the reduction of cooling loads of office buildings in Ghana
}

\section{Christian Koranteng, Barbara Simons and Kwabena Abrokwa Gyimah Kwame Nkrumah University of Science and Technology, Kumasi, Ghana}

\begin{abstract}
Purpose - Given the climatic context and economic challenge of Ghana in its developmental strides, energy use of office buildings continues to be a task on the economy. Therefore, the study was about finding measures that could reduce cooling loads in 10 office buildings. The paper presents the outcome of a long-term study of the thermal conditions in a selected number of office buildings in Accra and Kumasi, Ghana.

Design/methodology/approach - Through long-term monitoring of environmental data, the buildings were consequently modelled in a simulation application. Thereafter, a validation of the simulation models (using regression coefficients, $r^{2}$ of $0.53-0.90$ ) was undertaken towards finding measures to reduce cooling loads.

Findings - The results showed various potentials of efficient lighting, thermal mass, night ventilation, insulation to attic floors, efficient glazing, blind deployments, etc. in reducing cooling loads in the range of $2-17.5 \%$. By combining the potential measures to study their synergistic effects on the loads, 35,39 and $38 \%$ improvements were achieved for the low-rise, multi-storey and fully glazed office buildings.

Originality/value - These potential measures ought to be incorporated in the design, specification, construction and operation of Ghanaian office buildings to reduce the burden on the economy and the environment. Now more than ever, there is the need for climatic regions to come up with empirical data that could help relieve the world's economies from the post-pandemic stress.
\end{abstract}

Keywords Energy use, Cooling loads, Office buildings, Efficiency, Simulation, Climate, Multi-storey, Low-rise, Glazed buildings, Lighting, Night ventilation, Shading

Paper type Research paper

\section{Introduction}

In the wake of modernism, the current trend of architecture with large glazed areas has not been supported with the much needed energy framework to provide comfort in commercial buildings. The Energy Commission of Ghana (2006) confirmed that indeed Ghana's energy situation is dwindling. A challenge manifested by her expanding economy and growing population. Ghana's energy situation over the years has suffered major setbacks due to its over-reliance on hydropower sources. Ofei (2016) reported that the total installed generation capacity of Ghana is approximately 3,200 MW. Of this amount, 1,580 MW representing $49.9 \%$ is produced from hydropower sources (hydro plants of capacity more than $100 \mathrm{MW}$ are not considered as renewable energy (GOG, 2011), 1,579 MW representing $49.8 \%$ is from thermal plants and $8.2 \mathrm{MW}$ representing $0.3 \%$ is produced from renewable energy sources (Ofei, 2016). Ghana has over the years added unto its power generation plants, but the addition is barely satisfactory due to the current rate of population growth, urbanisation and developmental direction (industrialisation) of government. The situation is evident in the frequent power rationing which hit the country in 2016, and more recent signs of a decline

(C) Christian Koranteng, Barbara Simons and Kwabena Abrokwa Gyimah. Published in Frontiers in Engineering and Built Environment. Published by Emerald Publishing Limited. This article is published under the Creative Commons Attribution (CC BY 4.0) licence. Anyone may reproduce, distribute, translate and create derivative works of this article (for bothcommercial and non-commercial purposes), subject to full attribution to the original publication andauthors. The full terms of this licence may be seen at http://creativecommons.org/licences/by/4.0/legalcode
Reduction of cooling loads

Received 18 March 2021

Revised 30 April 2021

3 June 2021

13 July 2021

Accepted 15 July 2021

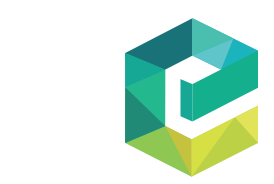

Frontiers in Engineering and Built Environmen Vol. 1 No. 2,2021 pp. $161-172$ Emerald Publishing Limite e-ISSN: $2634-2502$ DOI 10.1108/FEBE-03-2021-0016 
FEBE 1,2

have started to show. The Global Status Report for Buildings and Construction (2019) states that building construction and operations accounted for the largest share of both global final energy use (36\%) and energy-related $\mathrm{CO}_{2}$ emissions (39\%) in 2018. The same report account that from 2010 to 2018, global electricity use in buildings rose by over $19 \%$. Could this amount be reduced if more sustainable practices are adhered to? As energy is viewed as the most important engine to improve the quality of life and fight poverty, the onus lies on humanity to practice sustainable development by becoming energy efficient to save itself from possible extinction.

Energy efficiency is one of the main tools when it comes to the possibility of realising sustainable development. As the energy situation in the world all over is not getting any better, the current trend of buildings is partly to blame for this situation.

The study does illustrate potential design and systems measures to reduce cooling loads in Ghanaian low-rise and multi-storey office buildings through a simulation approach.

One of the key sustainable design measures is the orientation of a building. This eventually determines how much energy it would use to provide thermal comfort for its occupants. Seok-Hyun et al. (2014) affirm that the amount of sunshine is affected by the orientation of a building. During summer, the amount of sunshine at the east and west is small, but the west requires a larger cooling load in the afternoon because of the afternoon sunshine. The south has a larger amount of sunshine, but solar radiation can be blocked easily by shading. Aspect ratio, which is the ratio of the longer dimension of an oblong plan to the shorter (Szokolay, 2004), is seen to have a relationship with the orientation of a building. Szokolay further explains that depending on the temperature and radiation conditions, north and south walls should be longer than the east and west with an aspect ratio of about 1.3-2.0.

Shading is one of the methods for reducing the energy consumption of buildings while ensuring outside views. Shading can be inside or outside. According to Seok-Hyun et al. (2014), the ideal shading is to block solar radiation but achieve acceptable ventilation and view.

Generally, several studies in various geographical locations on the measures towards the reduction of cooling loads of office buildings have been conducted. Vinod et al. (2017) in Malaysia and Korea sought to investigate the existing methods for cooling load reduction and to compare and recommend the most suitable method to develop energy load prediction equations. The results were to be used to estimate the energy consumption of office buildings.

In India, Husain et al. (2017) found two scaled building models, i.e. model I (conventional design) and model II (green design) after having been examined with different design configurations. The authors found that the sensible heat transfer load of the building is reduced by $21-29 \%$ using fired aerated brick (FAB) with cavity wall in place of fired clay brick $(\mathrm{FCB})$ wall. The load reduction increases to $26-44 \%$ by using FAB cavity wall with reflective coating on the roof. This reduction further increases to $64-68 \%$ with $\mathrm{FAB}$ cavity wall along with green roof. In this final scenario, the monthly electrical energy saving for airconditioning is approximately $5.1 \mathrm{kWhe} / \mathrm{m}^{2}$ per unit envelope area, with an associated reduction in greenhouse gas emissions up to $6.36 \mathrm{~kg} \mathrm{CO} 2 \mathrm{eq} / \mathrm{m}^{2}$ per unit envelope area, assuming continuous operation of the HVAC systems.

Kwak et al. (2019) also found that improvement options of envelope features of four buildings yielded a $72 \%$ and a $24 \%$ drop in annual cooling energy consumption, resulting in an average decrement of $62 \%$ in $\mathrm{CO}_{2}$ emissions. The study then concluded that window space, window eaves, window characteristics, exterior wall insulation thickness, draft prevention, shading, landscaping features and control of solar energy, considerably reduce heating-cooling energy consumption, the amount and cost of natural gas, electricity, annual greenhouse gas emissions from heating and cooling energy. The study recommended architectural improvements aimed at energy-efficient design of building envelopes. 
Rana et al. (2020) suggested a window-to-wall ratio (WWR) of 30\%-40\% as the optimum range for air-conditioned office buildings in Bangladesh. An existing office building was able to save about $9.40 \%$ of electricity by incorporating optimum percentage of WWR. The output of this work was recommended to be incorporated into Bangladesh National Building Code as energy-efficient strategies for designing an air-conditioned office building to reduce heat loads and consequently, energy consumption.

Using a shade design, the daylighting performance and the reduction in cooling loads during the overheated periods of target buildings in various locations were evaluated by employing the daylight factor and useful daylight illuminance (Kim and Jeong, 2018). The authors found that the results showed a 35\% reduction in cooling loads due to the shading device and the shading performance is expected to vary among regions.

Nazi et al. (2015) also concluded that a sustainable building does not necessarily reduce high running cost of buildings even though installed technologies were chosen to suit the building's condition. A wide range of factors is to be monitored and adjusted for improved performance.

Based on experimental results, the use of cavity walls (fired aerated brick) with green roofing method showed an effective solution for sustainable building design, and Husain et al. (2017) therefore recommended further studies to examine other green building features, e.g. green wall, Earth air tunnel, alternative reflective coating on roof, etc.

Against the aforementioned, the current study seeks to explore measures that could reduce cooling loads in Ghanaian office buildings through a simulation approach.

\section{Methods}

\section{Selection of buildings}

The following representative group of buildings in the two largest cities of Ghana, thus, Accra and Kumasi, were selected for the studies.

\section{Five low-rise office buildings}

These buildings are in Kumasi having an area of $365-1,740 \mathrm{~m}^{2}$, and showing various WWR ratios $(5-42 \%)$. The area to volume ratio ranges from $0.27-0.33$. The conventional construction is the use of sandcrete walls with sliding glass as windows, thus, if not fitted with louvre blades. The orientations differ from each other, external shades are typically fixed in position and lights and internal shades are manually controlled. The cooling systems usually involve split air conditioner units. The building properties used for the parametric analysis are listed in Table 1.

\section{Four multi-storey office buildings}

The selected buildings (9,341-14,557 $\left.\mathrm{m}^{2}\right)$ dominate the skyline of Accra, have greater parts of the facades glazed, with a mix of split and central air-conditioners. Monitored offices have installed $40 \mathrm{~W}$ florescent tubes. The controls of the installed systems (blinds, fans, etc.) are manually operated. Floors are made of tiles and tongue and groove timber pieces, whilst ceilings are of suspended acoustic boards and partition walls are typically of gypsum boards.

$U_{\text {walls }}=3.4 \mathrm{Wm}^{-2} \mathrm{~K}^{-1} ; U_{\text {windows }}=2.7-5.84 \mathrm{Wm}^{-2} \mathrm{~K}^{-1} ; g_{\text {windows }}=0.49-0.82 ;$ day $/$ night $\mathrm{ACH}=1 / 0.5 \mathrm{~h}^{-1} ;$ lighting load $=6 \mathrm{Wm}^{-2}$; occupants' load $=10-14 \mathrm{Wm}^{-2}$; equipment load $=1-7 \mathrm{Wm}^{-2} ; U_{\text {attic floor }}=3.44 \mathrm{Wm}^{-2} \mathrm{~K}^{-1}$; floors carpeted

\section{Reduction of cooling loads}

163 
FEBE 1,2
Glazing ranges from single to double pane curtain walls on different orientations. Table 2 shows the properties used for the simulation exploration.

\section{A case of fully glazed building}

The case of a 13-storey fully glazed structure with an open floor plan was selected for the study because there are no shading elements on the building and it is located within a commercial suburb of Accra. The glazing used for the structure is a double type with internal blinds to screen the workspaces. Simulation parameters are outlined in Table 3.

\section{Climatic characteristics of case study cities}

Ghana lies between latitudes $4.50^{\circ} \mathrm{N}$ and $11.50^{\circ} \mathrm{N}$ and longitude $3.50^{\circ} \mathrm{W}$ and $1.30^{\circ} \mathrm{E}$. It is generally a tropical country. Accra and Kumasi (with the former being the Capital city of Ghana) are the two largest cities in the country in terms of population and economic development. Accra is located on the coast, whiles Kumasi is midland (Plate 1). According to Abass (2009) as cited in Simons (2015), the former climatically belong to the dry equatorial region and the latter wet-semi equatorial region. Localised climate within the various regions

Table 2.

Overview of base case simulation scenarios in Tas (multi-storey buildings)

\section{Description}

$U_{\text {windows }}=2.8-5.60 \mathrm{Wm}^{-2} \mathrm{~K}^{-1} ; g_{\text {windows }}=0.50-0.70 ;$ day/night $\mathrm{ACH}=1 / 0.5 \mathrm{~h}^{-1}$; lighting load $=3-8 \mathrm{Wm}^{-2}$; occupants' load (sensible and latent) $=4.8-10 \mathrm{Wm}^{-2}$; equipment load $=5-20 \mathrm{Wm}^{-2} ; U_{\text {attic floor }}=3.44 \mathrm{Wm}^{-2} \mathrm{~K}^{-1}$; floors carpeted, internal blinds; base case temp. $=26^{\circ} \mathrm{C}$
Table 3.

Overview of base case simulation scenarios in Tas $(100 \%$ glazed office building)
Description

$U_{\text {windows }}=5.60 \mathrm{Wm}^{-2} \mathrm{~K}^{-1} ; g_{\text {windows }}=0.77$; day/night $\mathrm{ACH}=1 / 0.5 \mathrm{~h}^{-1}$; lighting load $=8 \mathrm{Wm}^{-2}$; occupants' load (sensible and latent) $=8 \mathrm{Wm}^{-2}$; equipment load $=20 \mathrm{Wm}^{-2}$; floors carpeted, internal blinds; base case temp. $=26^{\circ} \mathrm{C}$
Plate 1.

Climatic regions of Ghana

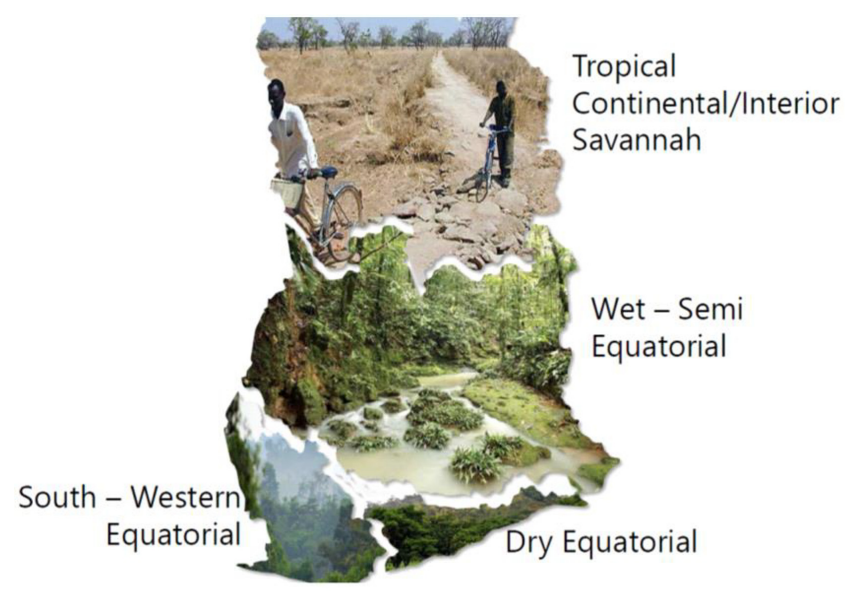

Source(s): Adapted from Abass, 2009 
shows Accra being slightly warmer than Kumasi. The country has high temperature values with the average annual temperature ranging between 24 and $30^{\circ} \mathrm{C}$. There are however variations over different parts mostly due to the effect of altitude and, more importantly, to the effect of distance from the sea. In spite of this average annual temperature, there are instances where the temperature can be 18 and $40{ }^{\circ} \mathrm{C}$ in the southern and northern parts of Ghana, respectively. Rainfall in Ghana generally decreases from south to north. The wettest area in Ghana is the extreme southwest where annual rainfall is about 2,000 $\mathrm{mm}$ (Asante and Amuakwa Mensah, 2015). Ghana has two main rainfall periods which are the double maxima regime and the single maximum regime. The two maximum periods are from April to July and from September to November in Southern Ghana. While the single maximum regime is from May to October in Northern Ghana, this is followed by a long dry season from November to May. With time, the temperature values in all the ecological zones of Ghana are rising, while rainfall levels have been generally reducing and patterns increasingly becoming erratic (Environmental Protection Agency, 2008).

\section{Monitored environmental data}

Environmental parameters of air temperature and relative humidity values were measured using Hobo sensors in selected spaces and outside of the buildings. The period of measurement ranged from 6 to 12 months.

\section{Validation of the simulation models}

Using the approach of Mahdavi et al. (2007), the simulation application used to probe potential measures with impact on cooling loads in the buildings was based on TAS, a thermal simulation software. TAS is a program for the assessment of thermal behaviour. It calculates the heating and cooling loads, resulting from inside and outside of buildings. The program adopts the mechanical simulation principle by tracking the thermal behaviour of the building via various snapshots taken every hour. This gives users a detailed image of the way the building performs (Lee et al., 2012). The normal sequence of performing simulation includes the 3D modeller, the building simulator and the results viewer. First, the 3D model maker is used for building the geometrical shape of the building and specifying the borders of each space. Then the geometrical shape, the building elements, zones and surfaces are sent to the building simulation application. In the course of sending, different calculations may be performed (EDSL, 2008). Briefly, the validation was grounded on measured data by inputting the material properties of the models (base case) in the parametric software. Furthermore, identified portions of a synthetic weather file for the locations (generated via Meteotest, 2016) that matched our measurements of outdoor conditions were used for the simulation. The comparison was based on achieving good regression coefficient values. Afterwards, the simulation results were used to compare measured and simulated indoor temperature values following the method of Mahdavi et al. (2007).

The whole experimental process (which was to find the best fit scenario/s that could reduce the energy use in the offices) followed the chart below (Figure 1).

\section{Parametric study of thermal improvement scenarios}

In order to explore potential measures to reduce cooling loads of the simulated and validated models, various options of building elements and system parameters were probed. The measures were centred on efficient glazing and lighting, ventilation options and schedules, thermal mass and shading. Moreover, various combinations were tried to see the synergistic effect of the measures on cooling energy loads (sensible and latent). The parameters of the simulation are illustrated in Table 4.
Reduction of cooling loads 


\section{FEBE}

1,2

166

Figure 1.

Systematic process of the simulation steps
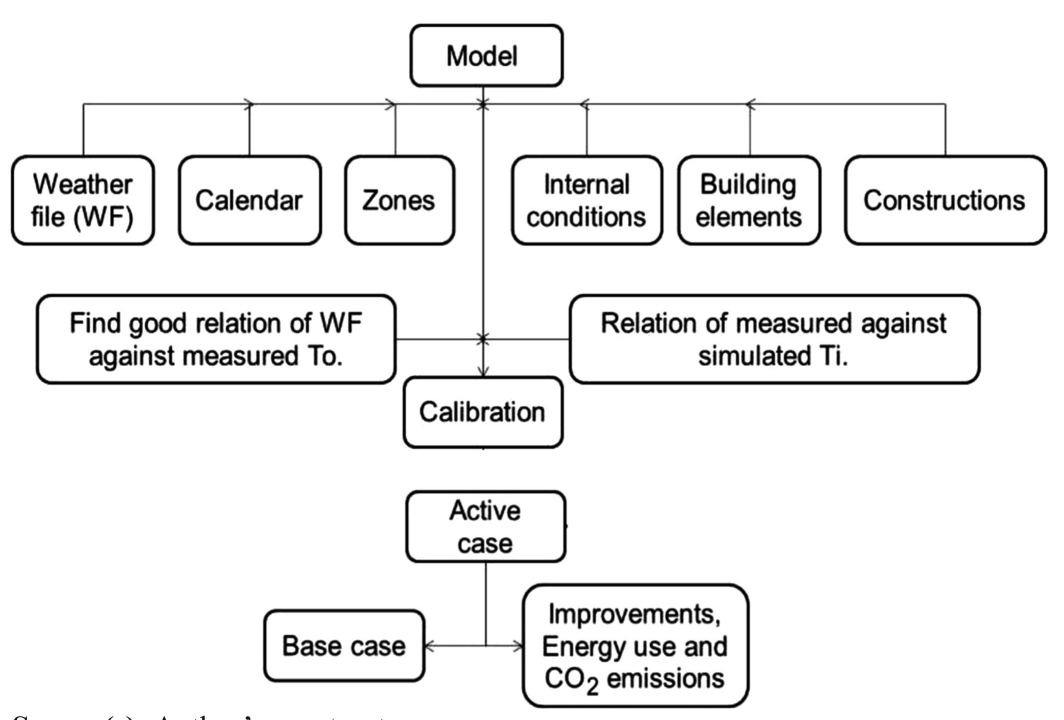

Source(s): Author's construct

\begin{tabular}{|c|c|}
\hline Building & Description \\
\hline Low-rise & $\begin{array}{l}U_{\text {walls }}=0.4 \mathrm{Wm}^{-2} \mathrm{~K}^{-1} ; U_{\text {windows }}=1.80 \mathrm{Wm}^{-2} \mathrm{~K}^{-1} ; g_{\text {windows }}=0.29 ; \text { day } / \text { night } \mathrm{ACH}=1 / \\
10 \mathrm{~h}^{-1} \text {; lighting load }=2 \mathrm{Wm}^{-2} ; U_{\text {attic floor }}=0.40 \mathrm{Wm}^{-2} \mathrm{~K}^{-1} ; \text { without floor carpets }\end{array}$ \\
\hline Multi-storey & $\begin{array}{l}U_{\text {windows }}=2.60 \mathrm{Wm}^{-2} \mathrm{~K}^{-1} ; g_{\text {windows }}=0.30 \text {; day } / \text { night } \mathrm{ACH}=10 / 10 \mathrm{~h}^{-1} ; \text { lighting } \\
\text { load }=2 \mathrm{Wm}^{-2} \text {; without floor carpets and suspended ceiling, internal blinds; external } \\
\text { blinds deployed during time of solar ingress }\end{array}$ \\
\hline $\begin{array}{l}100 \% \text { glazed } \\
\text { office }\end{array}$ & Same as multi-storey building \\
\hline
\end{tabular}

Table 4.

Overview of improved simulation scenarios

office

Energy consumption and $\mathrm{CO}_{2}$ emissions

In the estimation of the energy use resulting from the comparison of the base case and improvement scenarios cooling loads, the associated $\mathrm{CO}_{2}$ emissions $\left(0.259 \mathrm{~kg} \mathrm{CO} 2 . \mathrm{kWh}^{-1}\right)$, efficiency of the air-conditioners (COP of 2.6), unit price of electricity (3.1USD) and assumptions on the applicable energy mix in Ghana were used. Further, assumptions on the average $\mathrm{CO}_{2}$ emission per $\mathrm{kWh}$ of electricity for Ghana (0.259) were used as the basis in estimating the $\mathrm{CO}_{2}$ savings for the office buildings.

\section{Results and discussion}

Measured external air temperature values

A comparison of site measurements which was undertaken in 2019 and environmental parameters received from the official weather stations (covering the same year) showed a relatively good match.

\section{Weather file versus measured data}

To ensure a good fit between measurements at building sites and the generated synthetic weather file, the two plotted values when compared, showed an appreciable level of fitness. 
Sample plots are illustrated in Figure 2. A day in the warmest month for both Accra and Kumasi was used for the plot. For Accra, this was 4th March 2019, while for Kumasi, it was 21st February 2019.

From the figure, there is a relatively good match between values measured on-site and what was simulated. This gives an indication of the methodology (simulation) being superior and the results close to reality.

\section{Comparison of measurements and simulations}

Based on correlation coefficient values $\left(r^{2}\right)$, measured and simulated temperature values were compared. The comparison showed a close relation between measured and simulated in about $80 \%$ of all the case study buildings. The divergence in the values of the $r^{2}$ for the buildings $(0.53-0.90)$ is because of the difficulty involved in monitoring every activity in the office spaces. Specifically, the number of occupants at a time and their actions could not be observed due to financial challenges for acquiring full-scale monitoring devices. Again, data used for the plot for Accra were recorded on the 6th March 2019, whiles that for Kumasi were 25th February 2019.

\section{Parametric simulation on potential improvement scenarios}

Based on the validated simulation models in relation to improvement as well as combined improvement scenarios, the following observations were made.

The low-rise buildings were able to reduce cooling loads by $9 \%$ through the installation of efficient lighting. The reduction of cooling loads was insignificant $(2 \%)$ when the focus was
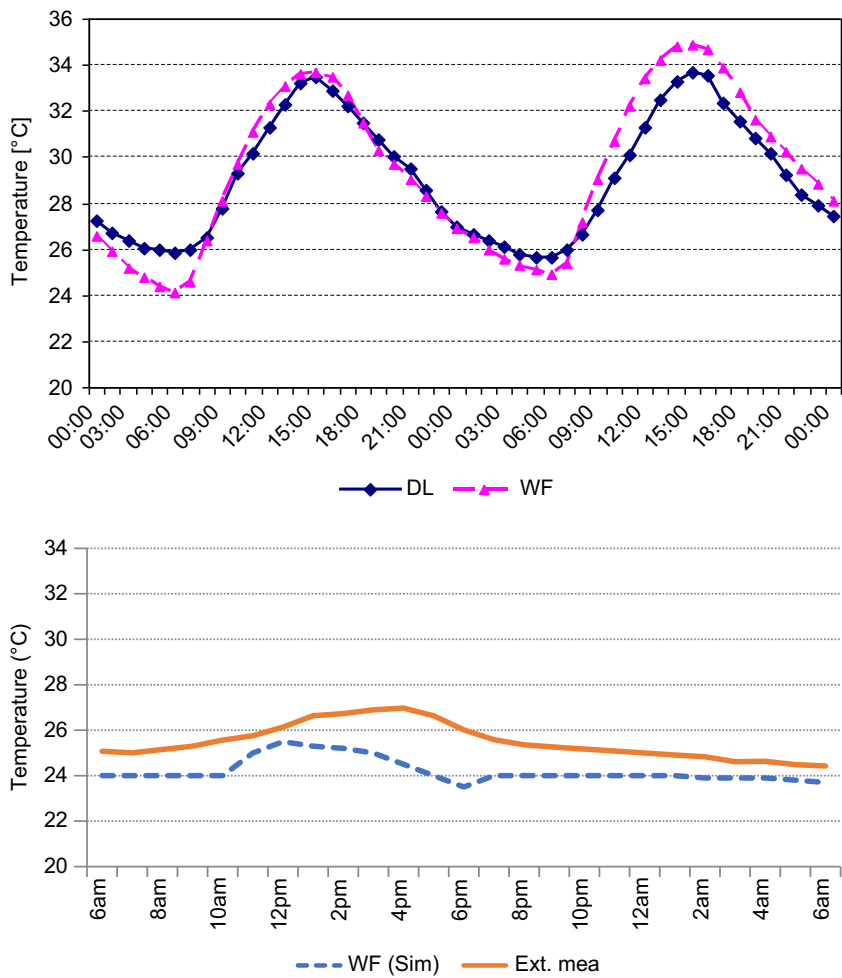

Reduction of cooling loads . 
FEBE 1,2

\section{8}

Figure 3.

Examples of simulated annual cooling loads $\left(\mathrm{kWh} \cdot \mathrm{m}^{-2} \cdot \mathrm{a}^{-1}\right)$ for the best scenarios and their percentage reduction on the thermal mass by exposing the floors to heat absorption. Night ventilation was able to reduce the loads by $8 \%$, and this was achieved through flushing the building with the cool night air. Concerning the ventilation and thermal mass decreases, it could be said that the tropical weather does not allow a wide diurnal range in temperature, as such, the building mass could not be cooled considerably. Thermal insulation of the walls led to about a 5\% reduction, whereby the insulation of attic floors and ceiling was able to improve cooling loads by $8 \%$. This calls for roofs to be well insulated as Ghana is close to the equator with intense solar radiation. The best improvement measure was from the efficient glazing $(14 \%)$ as this was arrived at through better shading effectiveness of the glass. A combination of the improvement scenarios (efficient windows, night-time ventilation and efficient lighting) and (improved attic floor insulation, improved windows, night-time ventilation and efficient lighting) could reduce low-rise buildings' cooling loads by $20-35 \%$.

The multi-storey structures performed well for the improvement measures as they did for the low-rise buildings. Sampled results are indicated below (Figure 3), whereas Table 5 shows the base case cooling loads of the studied buildings.
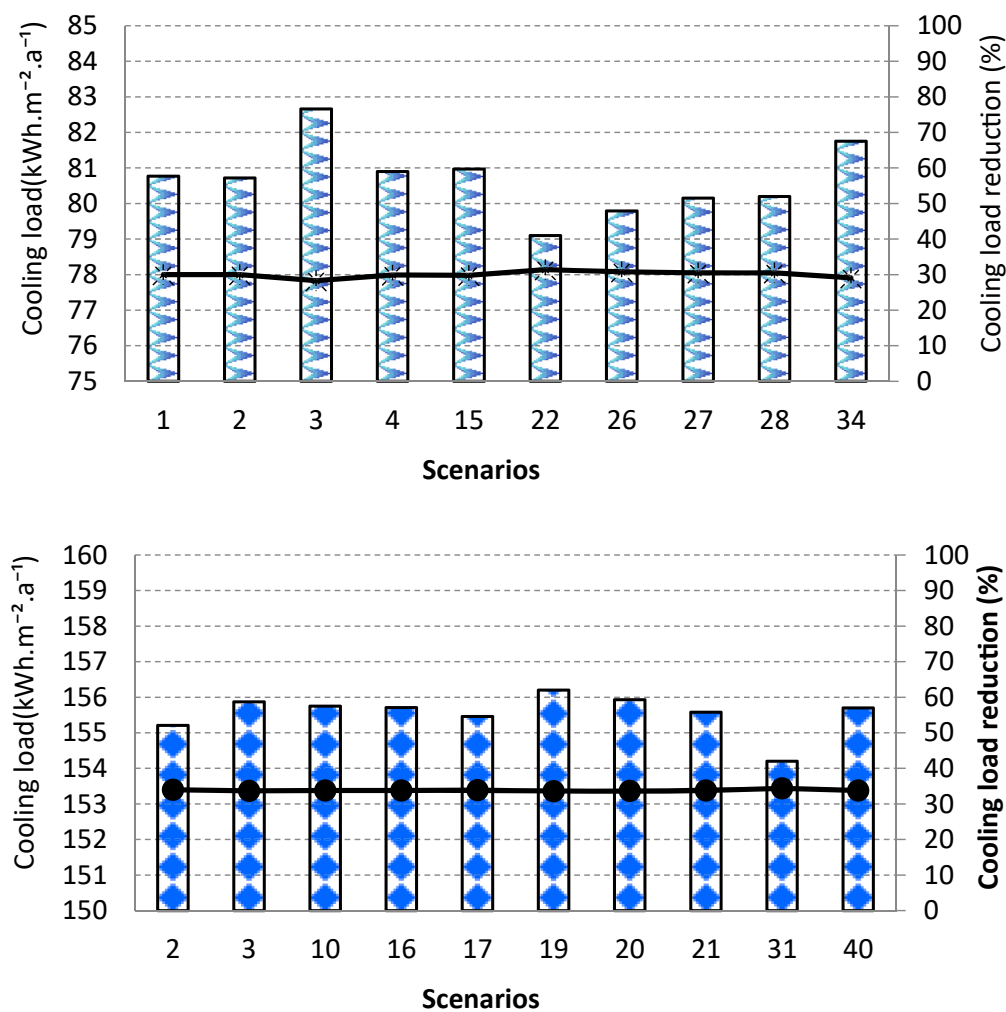

Table 5.

Base case cooling loads for the multi-storey buildings (M-S. 1-4)

\begin{tabular}{lllll}
\hline Building & M-S. 1 & M-S. 2 & M-S. 3 & M-S. 4 \\
\hline Cooling load $\left(\mathrm{kWhm}^{-2} \cdot \mathrm{a}^{-1}\right)$ & 115.34 & 149.75 & 168.44 & 235.16 \\
\hline
\end{tabular}


The probed alternative of a more efficient glazing type with a better shading coefficient (0.3) resulted in a significant reduction of the base case cooling loads by $14.1-26.6 \%$. The effect was that only $30 \%$ of radiation could be transmitted through the glass as compared to the ca. A total of $50 \%$ was at the base case scenarios. Such a high percentage could be due to the shading that is provided in some cases, by the verandah. According to Al-Tamimi et al. (2011), reducing the glazing to wall ratio helps reduce the cooling loads. A proper selection for the optimal area of the glass and applying natural ventilation system can reduce the negative effect of solar radiation in increasing the indoor air temperature (Al-Tamimi and Fadzil, 2010).

By using more efficient lighting systems, cooling loads could be reduced by $4-10.2 \%$. This corroborates studies that have concluded that lighting gains have a positive effect on cooling loads (Yufan and Hassim, 2011).

Night ventilation could reduce the base case cooling loads by as much as $11-13 \%$ depending on the time of the night. Though night ventilation from 6 p.m. to 6 a.m. reduced cooling loads considerably $(12.9 \%)$, that of 9 p.m. to 6 a.m. was found to be effective since the percentage reduction between the two was $0.7 \%$.

An increase in the building's thermal mass as simulated via the virtual removal of the floor carpeting and ceiling panels, however, led to a $3.2-4.6 \%$ increase in the base case cooling loads. This outcome could be related to the cooling effects being used up rapidly in the building. The effect of thermal mass in a hot humid climate as documented by Cheng and $\mathrm{Ng}$ (2005) has not worked so well here. Perhaps, this observation is so because the case study buildings lack the heavy massing that is important for heat transfer in thermal mass (AmosAbanyie et al., 2009) and a high diurnal temperature difference (Szokolay, 2004). However, combinations of thermal mass and night ventilation showed an improvement of $13.5 \%$.

Different external blind deployment times (when blind is in use) also led to the reduction of cooling loads by $2.3-7.6 \%$. The position of the glazing was also considered for the blind deployments. The use of external shading with proper opening schedules is a major factor for all the better-performing scenarios that were generated by combining the individual variables.

The introduction of insulation material of both 5 and $10 \mathrm{~cm}$ to the buildings' external façades, resulted in an increase in cooling loads (0.2-7.4\%) and decreases of $4.3 \%$ in some of the structures. This result could be due to the orientation of the building and the tightness of the envelope. Designing buildings with sealed windows and without reference to solar orientation, with high standards of comfort but without reference to operating costs and with the newest technology but without much sense of what tomorrow might bring must be reconsidered as the non-sustainable use of resources poses a danger to humanity (Koranteng, 2010). The result also agrees with Lauber's (2005) recommendation of using façade insulation to reduce cooling loads. This assertion however does not work for all buildings.

All the various improvements combined did reduce the base case cooling loads significantly. The best scenarios (shading, the right orientation and aspect ratio, efficient lighting, better glazing, night ventilation and thermal mass) did reduce cooling loads by $28.3-$ $49.3 \%$. This result is significant and has been achieved through improved and efficient building elements, as well as sustainable design principles.

The curtain wall building ( $100 \%$ glazing on all sides) showed similar results as the multistorey structure. Cooling loads reduced from 288 to $272 \mathrm{kWh} \cdot \mathrm{m}^{-2} \cdot \mathrm{a}^{-1}(5.6 \%)$ when efficient glazing was used. A thermostat set point reduction from 26 to $24^{\circ} \mathrm{C}$ led to an increment in cooling loads of $2 \%$. In addition, north-south orientation can reduce the loads by $1.7 \%$ compared to the other sides. This sustainable measure should be applied when designing and placing buildings. The synergistic effect of the combined improvement scenarios performed well in the multi-storey buildings. A reduction of 38\% in cooling loads was achieved.

The reductions of cooling loads when used to estimate the reductions in $\mathrm{CO}_{2}$ emissions resulted in a mean value of 61.0 tons for all the buildings. This modest result is due to the 
FEBE 1,2

energy mix in Ghana as energy production depends to a larger extent on hydropower plants $(67.12 \%)$.

\section{Conclusion}

In finding measures to reduce cooling loads of office buildings in Ghana, the study presented looked at ten buildings under the categories of low-rise, multi-storey and fully glazed buildings. After a validation effort to ensure that simulation models of the buildings performed like the actual monitored case studies, various measures were probed towards their effectiveness in reducing cooling loads. These potential measures (efficient lighting, thermal mass, night ventilation, efficient glazing and blind deployments) were further probed to find their synergistic effect on cooling loads. The multi-storey office buildings performed like the fully glazed building as their mean reduction of cooling loads using combined improvement scenarios was 39 and 38\%, respectively. Comparing the low-rise and the multistorey buildings led to the following conclusions:

(1) Efficient lighting of $2 \mathrm{~W} / \mathrm{m}^{2}$ led to a mean reduction of 9 and $7 \%$ on cooling loads for the low-rise and the multi-storey buildings.

(2) Thermal mass via the virtual removal of floor carpets and suspended ceilings could reduce cooling loads by $2-4 \%$.

(3) Cooling the building using night ventilation could reduce the loads by $8 \%$ and up to $13 \%$ for the low-rise and multi-storey structures.

(4) Thermal mass and night ventilation combined showed an improvement of ca.14\% on the loads.

(5) Insulation in walls (with polystyrene) showed a mean reduction of $4.5 \%$ for the buildings. However, some of the buildings studied showed an increase in cooling loads of up to $7 \%$. Wall insulation is therefore not one of the potential measures due to the inconclusiveness of the results. This calls for further studies to ascertain the reason behind the finding.

(6) Insulating attic floors showed an $8 \%$ reduction which should be encouraged in the context of Ghana, given our tropical climatic conditions.

(7) Efficient glazing through better shading effectiveness of the windows showed a mean reduction of ca. $18 \%$. This is an excellent result for the design, specification, construction, operation, and retrofit measures for Ghanaian office buildings.

(8) Blind deployment during times of direct sunshine on the buildings led to a $5 \%$ reduction for the multi-storey structures.

In all, combinations of potential measures leading to the synergistic reduction values showed that low-rise buildings could have a mean value of 35\% improved performance, with multistorey and fully glazed structures showing 39 and 38\% improvements. Considering the potential of this result, overall office buildings in the two major cities could lead to at least $37 \%$ energy savings. This huge potential could reduce the burden on the economy and the environment. It is therefore prudent for Ghana's higher institutions of learning (especially the built environment programmes) to train students to be mindful of these sustainable practices. The training could lead to the setting-up of energy audit firms to contribute to the Global Agenda of sustainable buildings. It would also be necessary for built environment professionals (especially architects) to probe buildings at the design stage to know beforehand their energy requirements. The success of these recommendations would be 
based on the government coming up with policies to ensure the energy certification of existing and new buildings. This could be tied into the building permitting process to ensure compliance. Finally, the study has provided empirical evidence for the improvement of thermal performance in office buildings in Ghana. Hitherto, this assertion had not been supported by any empirical study within the localised climate of Ghana. It is recommended that future research should consider other types of buildings (residential, industrial, etc.) where annual cooling loads are also considered to be high.
Reduction of cooling loads

\section{References}

Abass, K. (2009), A Regional Geography of Ghana for Senior High Schools and Undergraduates, Pictis Publications, Accra, ISBN: 978-9988-02796-6.

Al-Tamimi, N.A. and Syed Fadzil, S.F. (2010), "Experimental and simulation study for thermal performance analysis in residential buildings in hot-humid climate (comparative study)", Journal of Science and Technology, Vol. 15 No. 1, pp. 17-25.

Al-Tamimi, N.A., Syed Fadzil, S.F. and Harun, W.M.W. (2011), "The effects of orientation, ventilation, and varied WWR on the thermal performance of residential rooms in the tropics", Journal of Sustainable Development, Vol. 4 No. 2, pp. 142-149, doi: 10.5539/jsd.v4n2p142.

Amos-Abanyie, S., Akuffo, F.O. and Quagrain, V. (2009), "Unveiling energy saving techniques for cooling in residential buildings in Ghana", International Journal of Ventilation, Coventry, Vol. 1 No. 8, pp. 23-35.

Asante, F.A. and Amuakwa-Mensah, F. (2015), "Climate change and variability in Ghana: stocktaking”, Climate, Vol. 2015 No. 3, pp. 78-99, doi: 10.3390/cli3010078.

Cheng, V. and Ng, E. (2005), "Comfort temperatures for naturally ventilated buildings in Hong Kong”, Architectural Science Review, Vol. 49 No. 2, pp. 179-182.

EDSL (2008), A-TAS Version 8.5, Environmental Design Solutions, available at: http://edsl.net/main/ Software/Designer/Validation.aspx (accessed 26 April 2021).

Energy Commission of Ghana (2006), Strategic National Energy Plan: 2006-2020: Annex 1, Energy Supply to the Economy, Electricity, Energy Commission, Accra.

Environmental Protection Agency (2008), Ghana Climate Change Impacts, Vulnerability and Adaptation Assessments, Environmental Protection Agency, Accra.

Global Alliance for Buildings and Construction, International Energy Agency and the United Nations Environment Programme (2019), 2019 Global Status Report for Buildings and Construction: Towards a Zero-Emission, Efficient and Resilient Buildings and Construction Sector, United Nations Environment Programme, Nairobi.

Government of Ghana [GOG] (2011), Renewable Energy Act, Government of Ghana, Accra, pp. 1-28.

Husain, D., Shukla, S., Umrao, V.K. and Prakash, R. (2017), "Thermal load reduction with green building envelope", Open Journal of Energy Efficiency, Vol. 6, pp. 112-127, doi: 10.4236/ojee. 2017.63009.

Kim, T.H. and Jeong, Y.S. (2018), “Analysis of energy-related greenhouse gas emission in the Korea's building sector: use national energy statistics”, Energies, Vol. 11 No. 4, p. 855, doi: 10.3390/ en11040855.

Koranteng, C. (2010), "The energy performance of office buildings in Ghana", Journal of Science and Technology, Vol. 30 No. 2, pp. 114-127.

Kwak, Y., Kang, J.A., Huh, J.H., Kim, T.H. and Jeong, Y.S. (2019), “An analysis of the effectiveness of greenhouse gas reduction policy for office building design in South Korea", Sustainability, Vol. 11, p. 7172, doi: 10.3390/su11247172.

Lauber, W. (2005), Tropical Architecture, 1st ed., Prestel Verlag, Munich. 
FEBE 1,2

Lee, T.K., Cho, S.H. and Kim, J.T. (2012), "Residents' adjusting behaviour to enhance indoor environmental comfort in apartments", Indoor and Built Environment, Vol. 21 No. 1, pp. 28-40, doi: 10.1177/1420326X11420120.

Mahdavi, A., Orehounig, K., Mikats, N., Lambeva, L. and El-Habashi, A. (2007), Analyzing Traditional Buildings via Empirically Calibrated Building Performance Models, IBPSA, Beijing, pp. 71-78, ISBN: 0-9771706-2-4.

Meteotest (2016), "Meteonorm version 6.0", available at: www.meteotest.ch.

Nazi, W.I.W., Wang, Y. and Roskilly, T. (2015), "Methodologies to reduce cooling load using heat balance analysis: a case study in an office building in a tropical country", The 7th International Conference on Applied Energy (ICAE 2015), Vol. 75, Energy Procedia, No. 2015, pp. 1269-1274.

Ofei, G. (2016), Business Opportunities for Renewable Energy in Ghana, Rijksdienst voor Ondernemend.

Rana, J., Hasan, R., Sobuz, H.R. and Tam, V.W.Y. (2020), "Impact assessment of window to wall ratio on energy consumption of an office building of subtropical monsoon climatic country Bangladesh”, International Journal of Construction Management, Taylor and Francis. doi: 10. 1080/15623599.2020.1808561.

Seok-Hyun, K., Sun-Sook, K., Kwang-Woo, K. and Young-Hum, C. (2014), “A study on the proposes of energy analysis indicator by the window elements of office buildings in Korea”, Energy and Buildings, Vol. 73, No. 2014, pp. 153-165.

Simons, B. (2015), "Simulation - based exploration of the thermal performance of some multi-storey office buildings in Accra, Ghana”, PhD Thesis, Kwame Nkrumah University of Science and Technology.

Szokolay, S. (2004), Introduction to Architectural Science: The Basis of Sustainable Design, 1st ed., Architectural Press, Oxford.

Vinod, K.V., Jason, L. and Saqaff, A.A. (2017), “Comparative study of passive methods for reducing cooling load”, 9th International Conference on Applied Energy, ICAE 2017, Cardiff, UK, 21-24 August 2017.

Yufan, Z. and Hasim, A. (2011), “A comparison of the occupant comfort in a conventional high-rise office block and a contemporary environmentally-concerned building”, Building and Environment, No. 46, pp. 535-545.

\section{Further reading}

Eicker, U., Huber, M., Seeberger, P. and Vorschulze, C. (2006), "Limits and potentials of office buildings climatisation with ambient air”, Energy and Building, Vol. 38 No. 6, pp. 574-581.

\section{Corresponding author}

Barbara Simons can be contacted at: nanaakuaayebea@yahoo.co.uk

For instructions on how to order reprints of this article, please visit our website:

www.emeraldgrouppublishing.com/licensing/reprints.htm

Or contact us for further details: permissions@emeraldinsight.com 